Jurnal Inkofar * Volume 1 No. 1, Juli 2018 * ISSN: 2615-3645 (Print) / 2581-2920 (Online)

Tersedia secara online di: http://www.politeknikmeta.ac.id/meta/ojs/

\title{
PERANCANGAN PENILAIAN KINERJA BERDASARKAN KOMPETENSI DAN KPI (KEY PERFORMANCE INDICATOR) PADA PT. KMI
}

\author{
Doto $^{1}$, Zulfa Fitri Ikatrinasari ${ }^{2}$ \\ ${ }^{1}$ Magister Teknik Industri / Pasca Sarjana / Universitas Mercu Buana / \\ doto.kholil@gmail.com \\ ${ }^{2}$ Dosen Magister Teknik Industri / Pasca Sarjan / Universitas Mercu Buana / \\ hipni_ahmad@yahoo.com
}

\begin{abstract}
Performance assessment system conducted by PT. The current KMI is based on prentation record and retention of employees towards employee attitudes. The current rating system creates employee dissatisfaction as the employee's performance is not included in the performance appraisal system. Although this assessment has an impact on granting incentives or bonuses. Performance evaluation based on KPI (Key Performance Indicator) and Efficiency (Behavior) are designed to improve performance appraisal objectives, as well as identify employee weaknesses and plan employee efficiency development programs. This study was conducted qualitatively through an interview and Focus Group Activity (FGD), by simulating the production division. Based on the results of the employee survey, it was found that $85 \%$ stated more satisfied with the new evaluation system based on more objective and transparent reasons and $15 \%$ said preferred older systems. This is because with the new system, it requires them to provide support data in employee assessments..
\end{abstract}

Keywords : Performance Appraisal, competencies, Key Performance Indicator

\begin{abstract}
ABSTRAK
Sistem penilaian kinerja yang dilakukan oleh PT. KMI saat ini berdasarkan pada absensi dan ingatan atasan terhadap sikap karyawan tersebut. Sistem penilaian saat ini menimbulkan ketidakpuasan karyawan karena prestasi kerja karyawan tidak termasuk dalam sistem penilaian prestasi kerja. Padahal penilaian ini berdampak pada pemberian insentif atau bonus. Penilaian kinerja berdasarkan KPI (Key Performance Indicator) dan Kompetensi (Behavior) dirancang untuk meningkatkan objektifitas penilaian kinerja, serta mengidentifikasi kelemahan karyawan dan merencanakan program pengembangan kompetensi karyawan. Penelitian ini dalakukan secara kualitatif dengan interview dan Focus Group Activity (FGD), dengan melakukan simulasi di bagian produksi. Berdasarkan hasil survey terhadap karyawan, didapatkan bahwa 85\% menyatakan lebih puas dengan system penilaian yang baru dengan alasan lebih objektif dan transparan dan 15\% menyatakan lebih suka dengan system yang lama. Hal ini karena dengan system yang baru, menuntut mereka harus menyiapkan data pendukung dalam penilaian karyawan

Kata Kunci: Evaluasi kinerja (Performance Appraisal), Competencies, KPI (Key Performance Indicator)
\end{abstract}

\section{PENDAHULUAN}

Salah satu unsur yang memegang peranan sangat signifikan dalam suatu organisasi adalah sumber daya manusia, karena merupakan sumber daya yang digunakan untuk menggerakkan dan mensinergikan sumber daya lainnya untuk mencapai tujuan organisasi (wirawan, 2009). Sumber daya manusia yang handal,dapat diciptakan dengan melakukan pengelolaan sumber 
daya manusia yang baik di dalam sebuah perusahaan atau organisasi Salah satu pengelolaan sumber daya manusia dapat dilakukan melalui penilaian kinerja karyawan atau performance appraisal (Sinambela, 2012).

Penilaian kinerja adalah proses dimana organisasi mengevaluasi pelaksanaan kerja individu (sinambela,2012). Penilaian kinerja dapat dilakukan untuk memberikan informasi mengenai dapat dilakukannya promosi dan penetapan gaji. Promosi yang paling baik untuk meningkatkan motivasi karyawan adalah promosi berdasarkan kompetensi (Dessler, 2010). Kompetensi karyawan dapat diukur dengan melakukan penilaian kinerja.

Kompetensi adalah bagian dalam kepribadian seseorang dan dapat memprediksikan tingkah laku dan performansi secara luas pada semua situasi dan job tasks (Nurmianto dan Nurhadi, (2006). Beberapa organisasi menggunakan penilaian kompetensi berdasarkan kompetensi spencer. PT. KMI adalah mengambil referensi kompetensi spencer, tetapi dalam hal ini tidak secara menyeluruh digunakan dan penetapannya berdasarkan hasil diskusi dengan tim FGD di organisasi tersebut

Berdasarkan hasil wawancara dengan Manajer SDM di PT. KMI, diperoleh informasi bahwa PT. KMI belum memiliki standar penilaian kinerja karyawan dalam rangka kegiatan pemberian bonus, insentif atau promosi. Selama ini mekanisme pemberian insentif, bonus, atau promosi adalah berdasarkan absensi dan penilaian sikap selama satu periode oleh atasan saja.

PT. KMI belum memiliki konsep penilaian khusus yang spesifik dan terdokumentasi. Berdasarkan hasil wawancara dengan beberapa karyawan di PT. KMI konsep penilaian kinerja karyawan tiap 6 bulan untuk pemberian insentif yang dimiliki PT.KMI dinilai kurang cocok karena tidak merepresentasikan prestasi karyawan.

Berdasarkan latar belakang yang telah diuraikan di atas, maka tujuan penelitian ini difokuskan pada bagaimana merancang penilaian kinerja karyawan yang spesifik dan objektif untuk keperluan pemberian insentif, bonus atau promosi.

\section{TINJAUAN PUSTAKA}

\subsection{Manajemen Kinerja}

Menurut Aguinis (2008) manajemen kinerja adalah suatu proses berkelanjutan dalam mengidentifikasi, mengukur dan mengembangkan kinerja organisasi, dimana kinerja dan tujuan setiap individu terhubung dengan tujuan dan misi organisasi.

Definisi manajemen Kinerja di atas terdiri dari dua kompenen, yaitu:

1. Proses yang berkelanjutan

Manajemen kinerja selalu berkelanjutan, yang melibatkan proses tiada akhir dalam menentukan tujuan, observasi kinerja, dan memberikan coaching dan feedback secara berkelanjutan.

2. Terhubung dengan misi dan tujuan

Manajemen kinerja membutuhkan manajer yang dapat memastikan aktivitas karyawan dan output yang dihasilkan sesuai dan konsisten dengan tujuan organisasi, sehingga dapat membantu meningkatkan daya saing perusahaan. Manajemen Kinerja dibuat terhubung langsung antara kinerja pekerja dan tujuan organisasi, sehigga karyawan dapat berkontribusi secara langsung (Aguinis, 2008).

\subsection{Kontribusi Sistem Manajemen Kinerja}

Menurut Aguinis (2008) banyak keuntungan dari penerapan manajemen kinerja. Sistem Manajemenn Kinerja / Performance Management System (PMS), berkontribusi pada hal berikut:

1. Peningkatan motivasi kinerja

2. Peningkatan harga diri

3. Manajer mendapatkan wawasan tentang bawahan

4. Definisi dan kriteria tugas menjadi jelas 
Jurnal Inkofar * Volume 1 No. 1, Juli 2018 * ISSN: 2615-3645 (Print) / 2581-2920 (Online)

Tersedia secara online di: http://www.politeknikmeta.ac.id/meta/ojs/

5. Peningkatan wawasan dan pengembangan diri

6. Tindakan personil yang lebih adil dan tepat

7. Tujuan organisasi menjadi jelas

8. Karyawan menjadi lebih kompeten

9. Ada perlindungan yang lebih baik dari tuntutan hokum

10. Ada perbedaan yang lebih baik dan tepat waktu antara kinerja baik dan kinerja buruk

11. Pandangan supervisor tentang kinerja dapat dikomunikasikan dengan lebih jelas

12. Dapat memfasilitasi perubahan organisasi

\subsection{Proses Manajemen Kinerja}

Menurut Aguinis (2008) Proses Manajemen Kinerja adalah suatu proses berkelanjutan terkait dengan komponen komponen yang saling terkait satu sama lain dalam memberikan dampak terhadap system manajemen kinerja keseluruhan. Komponen-komponen dari proses manajemen kinerja terdiri dari (1) prasyarat (prerequisities), (2) perencanaan kinerja (performance planning), (3) pelaksanaan kinerja (performance execution), (4) penilaian kinerja (performance assessment), (5) review kinerja (performance review), dan (6) perbaikan kinerja dan kontrak (renewal and recontracting performance).

\subsubsection{Prerequisities}

Ada dua prasyarat penting yang diperlukan sebelum sistem manajemen kinerja diimplementasikan, yaitu (1) pengetahuan mengenai misi dan tujuan strategis organisasi dan (2) pengetahuan tentang pekerjaan yang akan dilakukan. Pengetahuan terhadap misi dan tujuan strategis organisasi merupakan hasil perencanaan strategis. Perencanaan strategis memungkinkan organisasi merumuskan secara jelas tujuan atau alasan keberadaan organisasi, tujuan yang ingin dicapai di masa depan, dan strategi apa yang diperlukan untuk mencapai tujuan tersebut. Sekali tujuan organisasi ditetapkan, maka dilakukan penjabaran tujuan pada masing-masing departemen selaras dengan organisasi tersebut.

\subsubsection{Performance Planning}

Setiap pekerja perlu memiliki pengetahuan tentang sistem manajemen kinerja. Realitanya, awal dari setiap siklus kinerja diawali dari pertemuan antara pekerja dengan supervisornya untuk mendiskusikan apa yang harus dikerjakan dan bagaimana mengerjakan suatu pekerjaan yang disepakati bersama. Dalam diskusi mengenai rencana kinerja tersebut dibahas dua hal yaitu hasil kerja (results) dan perilaku kerja (behaviors), serta rencana pengembangan (development plan).

\subsubsection{Results}

Hasil kerja (results) adalah apa yang harus dikerjakan atau luaran yang harus dihasilkan pekerja. Penentuan results memperhatikan tanggungjawab kunci dari suatu pekerjaan yang umumnya diterjemahkan dari deskripsi pekerjaan. Diskusi terhadap tujuan-tujuan penting dan terukur dari suatu pekerjaan menghasilkan standar kinerja. Standar kinerja memberikan informasi mengenai kinerja yang dapat dicapai dan tidak dapat dicapai (kaitannya dengan kualitas, kuantitas, biaya, dan waktu).

\subsubsection{Behaviors}

Walaupun pengukuran hasil kerja adalah penting, jika hanya fokus pada hasil kerja dapat memberikan bias atau gambaran yang tidak utuh mengenai kinerja pekerja. Misalnya, beberapa pekerjaan sulit untuk mencapai tujuan atau standar. Beberapa pekerjaan misalnya memiliki kendali dalam mengerjakan suatu pekerjaan tetapi tidak memiliki kendali terhadap hasilnya. Behaviors, atau bagaimana suatu pekerjaan dikerjakan, merupakan hal penting dalam tahap perencanaan. Diskusi mengenai behaviors menghasilkan kompetensi yang dapat diukur dalam KSAs yang kritis dalam menentukan perolehan hasil kerja. Contoh kompetensi adalah kemampuan menulis atau komunikasi, berfikir kreatif,dan lain sebagainya.

\subsubsection{Development Plan}

Tahap penting sebelum masuk ke tahap review kinerja adalah pekerja dan supervisor memiliki kesepakatan tentang rencana pengembangan terkait hasil kerja dan perilaku kerja. 
Diskusi mengenai hasil kerja memperhatikan tanggungjawab kunci, tujuan khusus dari setiap tanggungjawab, dan standar kinerja. Diskusi perilaku kerja memperhatikan kompetensi yang diperlukan (dalam KSAs). Rencana pengembangan memuat deskripsi area yang memerlukan pengembangan dan tujuan yang harus dicapai di setiap area.

\subsubsection{Performance Execution}

Walaupun pekerja merupakan penanggungjawab utama terhadap pelaksanaan kinerja, manajer juga perlu berkontribusi untuk keberhasilan pekerjaan tersebut. Monitoring kinerja dari rekan kerja diidentifikasi sebagai kompetensi kunci oleh Pusat Standar Kinerja (www.management-standards.com Unit B5).

\subsubsection{Performance Assessment}

Pekerja dan manajer bersama-sama bertanggungjawab melakukan evaluasi terhadap perilaku yang diharapkan dan hasil yang harus dicapai. Walaupun banyak sumber dapat digunakan untuk mengumpulkan informasi kinerja, misalnya rekan kerja, bawahan, pada banyak kasus atas langsung yang mengumpulkan informasi kinerja.

\subsubsection{Performance Review}

Pertemuan antara pekerja dan manajer untuk mereview hasil kerja mereka adalah hal yang sangat penting, karena menyediakan kesempatan formal dimana pekerja menerima feedback terhadap hasil pekerjaannya.

\subsection{Keterkaitan Manajemen dan Rencana Strategis}

Menurut Aguinis (2010), untuk memastikan bahwa strategi dijabarkan hingga level terendah di organisasi dan mendorong tindakan konkrit, diperlukan upaya untuk mengaitkan rencana strategis dengan kinerja individu (Aguinis, 2010).

Keterkaitan antara rencana strategi organisasi, rencana strategi unit, job description, serta kinerja individu dan tim, ditunjukkan pada gambar 1 .

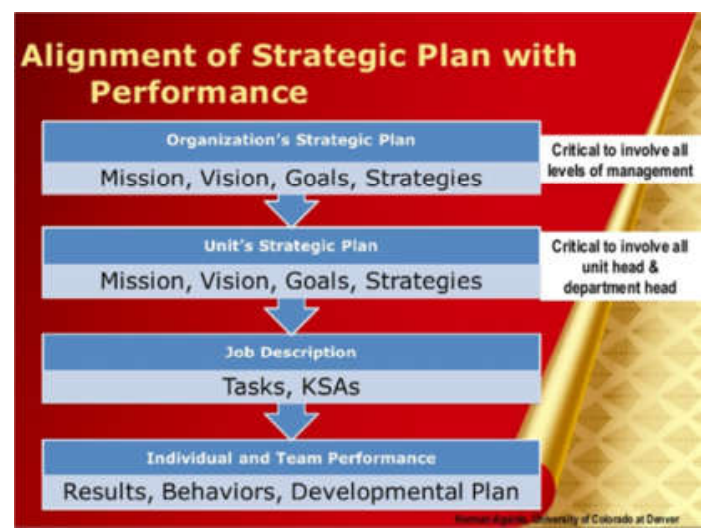

Gambar. 1. Keterkaitan majemen kinerja dengan rencana strategis

\subsubsection{Misi}

Pernyataan misi memberikan informasi tentang tujuan organisasi dan ruang lingkup kegiatannya.

\subsubsection{Visi}

Visi organisasi adalah pernyataan mimpi organisasi di masa depan, akan menjadi seperti apa organisasi di masa depan (sekitar 10 tahun yang akan rilis). Pernyataan visi umumnya dibuat setelah pernyataan misi mampu dihasilkan karena sebelumnya perlu tahu tujuan organisasi sebelum memberikan gambaran organisasi di masa depan. Pada banyak kasus, pernyataan visi biasanya memasukkan dua komponen yaitu core ideology dan visi masa depan.

\subsubsection{Tujuan}

Setelah organisasi menganalisis peluang dan ancaman lingkungan eksternal serta kekuatan dan kelemahan lingkungan internal, misi dan visi juga telah dirumuskan, tahap selanjutnya adalah mengembangkan tujuan yang realistis untuk mencapai misi organisasi. Tujuan 
memberikan informasi spesifik bagaimana misi akan diimplementasikan. Tujuan juga bisa menjadi sumber motivasi dan memberikan target kinerja yang terukur bagi pekerja. Tujuan juga memberikan dasar yang baik dalam pengambilan keputusan untuk luaran yang diinginkan. Akhirnya, tujuan memberikan kerangka bagi pengukuran kinerja karena akan memungkinkan untuk membandingkan apa yang harus dicapai dan apa yang mampu dicapai setiap unit, kelompok, dan unit.

\subsubsection{Strategi}

Setelah mengetahui apa yang menjadi tugas organisasi (misi), apa yang diinginkan organisasi di masa depan (visi), dan tahapan antara mencapai misi (goals), maka yang berikutnya adalah bagaimana memenuhi visi dan misi dan bagaimana mencapai tujuan. Hal ini dilakukan dengan memilih strategi, yang mendeskripsikan rencana bagaimana prosedur untuk nmencapai tujuan-tujuan yang telah direncanakan. Strategi biasanya memperhatikan isu-isu pertumbuhan, bertahan, turn around, stabilitas, inovasi, leadership, dibandingkan yang lainnya. Fungsi sumberdaya manusia (SDM) organisasi memainkan peran penting dalam mengembangkan dan menerapkan strategi sehingga visi dan misi organisasi terwujud. Secara khusus fungsi SDM dapat memberikan kontribusi dalam hal-hal berikut:

1. Mengkomunikasikan pengetahuan tentang rencana strategis.

2. Merumuskan KSA yang diperlukan untuk implementasi strategi.

3. Mengusulkan sistem reward

\subsection{Penilaian Kinerja berdasarkan kompetensi}

Penilaian kinerja berdasarkan KPI (key performance Indicator) dan Kompetensi (behavior) menunjukkan tingkat keakuratan lebih baik ditinjau dari aspek realibility, relefansi, sensitifitas dan kemudahannya (Mayasari et al, 2012).

Penilaian kinerja berdasarkan kompetensi, operator dapat mengetahui kelebihan dan kelemahan performansinya sehingga untuk menjadi bahan evaluasi serta dapat meningkatkan insentif dengan bekerja lebih baik lagi (Hidayat et al, 2011).

Menurut Susanti dan Fauziah (2014), dengan penilaian kinerja berdasarkan kompetensi dapat dengan mudah mengetahui operator yang berkinerja baik dan berkinerja buruk.

\section{HASIL, ANALISA, DAN PEMBAHASAN}

Berikut ini adalah hasil wawancara dan diskusi dengan Manajer Produksi, Supervisor produksi dan beberapa operator yang tergabung dalam Focus Group Discussion (FGD).

\subsection{Visi Perusahaan}

Menjadi perusahaan yang bergerak dibidang pembuatan painting line terbaik di Indonesia 2030.

\subsection{Misi Perusahaan}

Melakukan perbaikan terus menerus agar didapatkan proses terbaik yang lebih efektif dan efisien.

\subsection{Kebijakan Perusahaan}

1. Memenuhi spesifikasi produk yang ditetapkan untuk mencapai kepuasan pelanggan, mutu, delivery, dan peraturan yang berlaku.

2. Memberikan penawaran harga yang kompetitif dan delivery on time

3. Melakukan perbaikan terus menerus untuk menciptakan produk terbaik, proses terbaik dengan biaya terendah melalui pengembangan sumberdaya manusia

\subsection{Sasaran Perusahaan}

Dari kebijakan perusahaan tersebut ditetapkan sasaran perusahaan sebagai berikut:

1. Keluhan pelanggan maksimal $1 \%$ dari total produk yang dikirimkan ke pelanggan

2. Pengiriman barang ke pelanggan $100 \%$ tepat waktu.

3. Semua karyawan memiliki kompetensi sesuai standard minimal 85\%. 


\subsection{Sasaran Departement}

Dari sasaran perusahaan yang ditetapkan tersebut, maka sasaran Departement (manajer) ditetapkan, dan kemudian akan diturunkan lagi menjadi KPI (key performance indicator) untuk setiap individu. Berikut ini contoh KPI dan Kompetensi yang dihasilkan dari tim Focus Group Discussion.

Tabel 1.

\begin{tabular}{|c|c|c|c|c|c|}
\hline No & Kebijakan & Sasaran & Departemen & Sasaran Departemen & Target \\
\hline \multirow[t]{6}{*}{1} & \multirow{6}{*}{$\begin{array}{c}\text { Memenuhi } \\
\text { Persyaratan } \\
\text { pelanggan, } \\
\text { Mutu, delivery } \\
\text { dan peraturan } \\
\text { yang berlaku }\end{array}$} & \multirow{6}{*}{$\begin{array}{c}\text { Keluhan } \\
\text { Pelanggan } \\
\text { maksimal } \\
1 \% \text { dari } \\
\text { total } \\
\text { produk } \\
\text { yang } \\
\text { dikirimke } \\
\text { pelanggan }\end{array}$} & \multirow[t]{3}{*}{ Sales } & $\begin{array}{l}\text { Keluhan terkonfirmasi } \\
\text { (delivery, packaging, } \\
\text { document) }\end{array}$ & maksimal 1\% \\
\hline & & & & $\begin{array}{l}\text { Indek kepuasan } \\
\text { pelanggan }\end{array}$ & Min 3 (skala 1-4) \\
\hline & & & & $\begin{array}{l}\text { Response penanganan } \\
\text { keluhan pelanggan }\end{array}$ & maks 2X24 Jam \\
\hline & & & Warehouse & $\begin{array}{l}\text { Akurasi Delivery (waktu, } \\
\text { jumlah) }\end{array}$ & $\min 99 \%$ \\
\hline & & & QC & Kelolosan inspeksi & maks $0,5 \%$ \\
\hline & & & Produksi & First pass rate & $\min 99 \%$ \\
\hline \multirow[t]{8}{*}{2} & \multirow{8}{*}{$\begin{array}{c}\text { Memberikan } \\
\text { penawaran } \\
\text { haraga yang } \\
\text { kompetitive } \\
\text { dan delivery } \\
\text { on time }\end{array}$} & \multirow{8}{*}{$\begin{array}{l}\text { Delivery on } \\
\text { time } 99 \%\end{array}$} & \multirow{2}{*}{$\mathrm{SCM}$} & $\begin{array}{l}\text { On time delivery material } \\
\text { dari supplier }\end{array}$ & $\min 99 \%$ \\
\hline & & & & $\begin{array}{l}\text { Kesalahan pembelian } \\
\text { (jumlah, material) }\end{array}$ & Maks 1\% \\
\hline & & & Warehouse & $\begin{array}{l}\text { Akurasi delivery tepat } \\
\text { waktu }\end{array}$ & $\min 99 \%$ \\
\hline & & & \multirow[t]{2}{*}{ Maintenance } & Breakdown time & Maks 1\% \\
\hline & & & & Open WO & Maks $1 \%$ \\
\hline & & & PPIC & $\begin{array}{l}\text { Ketepatan Jadwal } \\
\text { Produksi }\end{array}$ & $\min 99 \%$ \\
\hline & & & \multirow[t]{2}{*}{ Produksi } & Quantity sesuai target & $\min 99 \%$ \\
\hline & & & & Quantity sesuai jadwal & $\min 99 \%$ \\
\hline \multirow[t]{2}{*}{3} & \multirow{2}{*}{$\begin{array}{c}\text { Melakukan } \\
\text { perbaikan } \\
\text { terus menerus } \\
\text { dengan } \\
\text { pengembangan } \\
\text { sumber daya } \\
\text { manusia }\end{array}$} & \multirow{2}{*}{$\begin{array}{c}\text { Setiap } \\
\text { karyawan } \\
\text { memiliki } \\
\text { kompetensi } \\
\text { standard } \\
\text { minimal } \\
85 \%\end{array}$} & $\begin{array}{c}\text { All } \\
\text { Departmen }\end{array}$ & Kompetensi per individu & Min $85 \%$ \\
\hline & & & HRD & Jumlah Training & $\begin{array}{c}\text { Min } \\
\text { 2X/individu/tahun }\end{array}$ \\
\hline
\end{tabular}

\subsection{Contoh evaluasi kinerja Departemen Produksi}

Tabel 2. Contoh hasil evaluasi kinerja

\begin{tabular}{|r|r|l|r|r|r|r|r|}
\hline No & $\begin{array}{c}\text { Area } \\
\text { Kinerja } \\
\text { Utama }\end{array}$ & \multicolumn{1}{|c|}{$\begin{array}{c}\text { Key perforance } \\
\text { Indicator }\end{array}$} & $\begin{array}{c}\text { Bobot } \\
\text { KPI }\end{array}$ & Target & $\begin{array}{c}\text { Realisasi } \\
\text { akhir } \\
\text { tahun }\end{array}$ & Skor & $\begin{array}{c}\text { Skor } \\
\text { akhir }\end{array}$ \\
\hline 1 & Produksi & $\begin{array}{l}\text { Quantitity sesuai } \\
\text { target waktu }\end{array}$ & 50 & $95 \%$ & $98 \%$ & 103 & 51,5 \\
\hline & & Quantitity defect & 30 & $2 \%$ & $1,50 \%$ & 133 & 39,9 \\
\hline & & peningkatan & 20 & $85 \%$ & 80 & 94 & 18,8 \\
\hline
\end{tabular}


Jurnal Inkofar * Volume 1 No. 1, Juli 2018 * ISSN: 2615-3645 (Print) / 2581-2920 (Online)

Tersedia secara online di: http://www.politeknikmeta.ac.id/meta/ojs/

\begin{tabular}{|l|l|l|l|l|l|l|} 
& Kompetensi & & & & & \\
\hline & & & 100 & & & \\
\hline
\end{tabular}

\section{Tabel 3. Contoh evaluasi kinerja behavior}

\begin{tabular}{|c|c|c|c|c|c|c|}
\hline \multirow[b]{2}{*}{ No. } & \multirow[b]{2}{*}{ ASPEK Kompetensi } & \multicolumn{5}{|c|}{ Nilai } \\
\hline & & 1 & 2 & 3 & 4 & 5 \\
\hline \multirow[t]{2}{*}{1} & Quality Orientation & & & & & \\
\hline & $\begin{array}{l}\text { Kecakapan untuk mengerjakan tugas dengan tuntas, tepat waktu } \\
\text { dan dengan mutu hasil pekerjaan yang prima atau sesuai, bahkan } \\
\text { diatas standar mutu yang telah ditetapkan. }\end{array}$ & & & & 4 & \\
\hline \multirow[t]{2}{*}{2} & Problem Solving Skills & & & & & \\
\hline & $\begin{array}{l}\text { Kecakapan untuk menganalisa masalah, mengidentifikasi sumber } \\
\text { penyebab masalah dan hubungan antar berbagai faktor masalah; } \\
\text { dan kemudian merumuskan alternatif solusi yang relevan dan } \\
\text { aplicable. }\end{array}$ & & & & 4 & \\
\hline \multirow[t]{2}{*}{3} & Planning Skills & & & & & \\
\hline & $\begin{array}{l}\text { Kecakapan untuk menyusun perencanaan kerja secara sistematis } \\
\text { dan terjadwal dengan baik; melakukan alokasi sumber daya } \\
\text { berdasarkan hasil perencanaan; serta melakukan monitoring } \\
\text { untuk memastikan rencana kerja dapat berjalan dengan efektif. }\end{array}$ & & & & 4 & \\
\hline \multirow[t]{2}{*}{4} & Teamwork & & & & & \\
\hline & $\begin{array}{l}\text { Kecakapan untuk melakukan koordinasi dan komunikasi dengan } \\
\text { berbagai pihak yang terkait; merumuskan tujuan bersama dan } \\
\text { berbagi tugas untuk mencapai sasaran kerja yang telah } \\
\text { ditetapkan; serta saling menghargai pendapat dan masukan guna } \\
\text { peningkatan kinerja tim. }\end{array}$ & & & 3 & & \\
\hline \multirow[t]{4}{*}{5} & Self Learning Capacity & & & & & \\
\hline & $\begin{array}{l}\text { Kecakapan untuk melakukan proses pembelajaran aktif - baik } \\
\text { secara mandiri ataupun berkelompok; menunjukkan minat yang } \\
\text { memadai untuk terus mengembangkan ketrampilan diri; dan } \\
\text { proaktif dalam melakukan sharing knowledge diantara sesama } \\
\text { karyawan. }\end{array}$ & & & 3 & & \\
\hline & & \multicolumn{5}{|c|}{$18 / 5 *(20)$} \\
\hline & & \multicolumn{5}{|c|}{72} \\
\hline
\end{tabular}

\subsection{Pembobotan dan Penilaian Kinerja}

Setelah diskusi dengan tim FGD, disepakati pembobotannya adalah:

1. KPI (Key Performance Indicator) : 60\%

2. Kompetensi (behaviors) : $40 \%$

Dari contoh (yang diuraikan dalam slide sebelumnya) terdapat data sbb:

Skor KPI $=110$; Skor Kompetensi $=72$

Maka Skor Total $=(60 \%$ x 110) $+(40 \%$ x 72$)=94,8$

Selanjutnya dibuat standard sebagai berikut:

1. Nilai $\mathrm{A}=\mathrm{X}>90$

2. Nilai $\mathrm{B}=80<\mathrm{X}<90$

3. Nilai $\mathrm{C}=\mathrm{X}<80$

Selanjutnya akan ditentukan besaran bonus, insentif, kenaikan gaji atau standard promosi.

\section{KESIMPULAN}

Setelah penerapan system penilaian kinerja, dilakukan survey untuk mendapatkan feed back dari karyawan. Berdasarkan hasil survey di dapatkan bahwa $85 \%$ menyatakan lebih puas dengan sistem penilaian yang baru dengan alasan lebih objective dan transparan dan $15 \%$ menyatakan lebih suka dengan system yang lama. Hal ini karena dengan sistem yang baru, menuntut mereka harus menyiapkan data pendukung dalam penilaian karyawan. 


\section{DAFTAR PUSTAKA}

Aguinis, H. 2008. Performance Management. 2nd ed., New York, NY: Prentice Hall. Wirawan. 2009. Evaluasi Kinerja Sumber Daya Manusia. Jakarta: Salemba Empat.

Sinambela, L.P.. 2012. Kinerja Pegawai. Jakarta: Graha Ilmu

Dessler, G. 2010. Manajemen Sumber Daya Manusia Edisi Kesepuluh Jilid 2. Jakarta: Index,

Camp, R. 1989. The search for industry best practices that lead to superior performance. Jakarta : Productivity Press.

Heizer \& Render. 2012. Manajemen Operasi dan Supply Chain Manajemen. Boston : Fearson

Manullang, M. 2015. Manajemen Personalia. Yogyakarta:Gajah Mada University Perss.

Saaty, T.L. dan Vargas, L.G. 2012. Models, Methods, Concepts and Applications of the Analytic Hierarchy Process (Second Edition). New York: Springer

Nurmianto, E. dan Siswanto, N. 2006. "Perancangan Penilaian Kinerja Karyawan berdasarkan Kompetensi Spencer dengan Metode AHP.” Jurnal Teknik Industri, Vol. 8(1), pp. 40-53.

Rimantho, D. Cahyadi, B. Dermawan, D. 2015. "Application analytic hierarchy process (AHP) by utilizing the Expert Choice as a tool in decision-making: a case study of ewaste management in Surabaya, Indonesia." In Conference Proceedings 8th International Seminar on Industrial Engineering and Management, Malang, Jawa Timur.

Damayanti, E. 2008. Perancangan sistem penguk uran k inerja dengan metode balanced scorecard. Jurnal Teknik Industri. Vol. 9 No.2 Agustus 2008

Mayasari, I., Haryanti, K. dan Hindiarto, F. 2012. Penilaian Kinerja Berdasarkan Kompetensi dan KPI (Key performer indicator) Perusahaan daerah Air minum Kabupaten Semarang. Prediksi, Kajian Ilmiah Psikologi - No. 2, Vol . 1 , Juli Desember 2012, hal. $224-228$

Hidayat, T.P. Sukwadi, R. dan Ngaditeja, J. 2011. Perancangan Sistem Kinerja karyawan (Studi kasus PT.X), J@TI Undip, Vol VI, No 1, Januari 2011

Nugraha, E. dan Sari, R.M. 2016. Perancangan Sistem Penilaian Kinerja Karyawan Berbasis Kompetensi, ISSN. 1412-0100, Vol 17, N0 2, Oktober 2016 